\title{
A new perspective on the shielding property of positive polarity*
}

\author{
Andreea C. Nicolae \\ Leibniz-Zentrum Allgemeine \\ Sprachwissenschaft
}

\begin{abstract}
In certain languages, disjunctions exhibit positive polarity behavior, which Szabolcsi (2002) argues can be diagnosed via the following four properties: (i) antilicensing: no narrow scope interpretation under a clausemate negation, (ii) rescuing: acceptable in the scope of an even number of negative operators, (iii) shielding: acceptable under a clausemate negation if a universal quantifier intervenes, and (iv) locality of anti-licensing: acceptable in the scope of an extra-clausal negation. In recent work, Nicolae (2016, 2017), building on Spector 2014, argues that what distinguishes PPI disjunctions from polarity insensitive disjunctions is the fact that PPI-disjunctions obligatorily trigger epistemic inferences. That analysis, however, only accounts for the first two PPI properties. This paper extends that analysis to account for the second two properties, concluding that they should be seen as instantiations of the same phenomena, namely shielding by a universal quantifier.
\end{abstract}

Keywords: positive polarity, disjunction, exhaustification, alternatives, pruning

\section{Overview}

In certain languages, disjunctions exhibit PPI behavior, diagnosable by four properties, outlined below (Szabolcsi 2002, 2004). This paper will present data focusing on the French plain disjunction ou 'or' and the Hungarian plain disjunction vagy.

Anti-licensing: the disjunction cannot receive a narrow scope interpretation in the scope of a clausemate negation; only a wide scope interpretation is available.

Marie n'a pas invité Léa ou Jean à dîner.

'Marie has not invited Lea or Jean for dinner.'

* I'm grateful to Gennaro Chierchia, Luka Crnič, Danny Fox, Berit Gehrke, Andreas Haida, Winnie Lechner, Clemens Mayr, Marie-Christine Meyer, Uli Sauerland, Benjamin Spector and Yasu Sudo, as well as audience members at ZAS, MIT, Utrecht, Göttingen, UCL, SALT 27 and the 2017 LSA. Many thanks to my French and Hungarian consultants as well, Isabelle Charnavel, Alexandre Cremers and Jérémy Zehr, as well as Beata Gyuris and András Bárány. This research was funded by the German Federal Ministry of Research (BMBF Grant Nr. 01UG1411). All errors are my own.

C2017 Nicolae 
Shielding PPIs

a. $\quad$ LF: $\neg p \vee \neg q$

lit: Mary didn't invite Léa or she didn't invite Jean for dinner.

b. $\quad * L F: \neg p \wedge \neg q$

lit: Mary didn't invite Léa and she didn't invite Jean for dinner.

(2) Nem csuktuk be az ajtót vagy az ablakot.

'We didn't close the door or the window.'

a. $\quad$ LF: $\neg p \vee \neg q$

lit: We didn't close one or the other, I don't know which.

b. *LF: $\neg \mathrm{p} \wedge \neg \mathrm{q}$

We closed neither the door nor the window.

Rescuing: the disjunction is acceptable in the scope of an even number of downward entailing operators.

(3) a. Tout étudiant qui n'a pas pris de cours de maths ou de physique a raté

l'examen.

'Every student who didn't take math or physics failed the exam.'

LF: $\forall x[\neg(p(x) \vee q(x)) \rightarrow r(x)] \equiv \forall x[(\neg p(x) \wedge \neg q(x)) \rightarrow r(x)]$

lit: The students who took neither math nor physics failed the exam.

b. Si Paul n'avait pas invité Pierre ou Julie, cela aurait été impoli.

'If Paul had invited neither Pierre nor Julie, it would've been rude.'

(4) a. Kevés fiú nem hívta fel Katit vagy Marit.

'Few people didn't call Kati or Mari.'

b. Ha nem hívod fel Katit vagy Marit, véged.

'If you don't call Kati or Mari, you are doomed.'

Shielding: the disjunction is acceptable in the scope of a clausemate negation if a universal item intervenes at logical form.

(5) Mary n'est pas toujours allée voir John ou Bill.

'Mary didn't always visit John or Bill.'

LF: $\neg \forall \mathrm{t}[\mathrm{p}(\mathrm{t}) \vee \mathrm{q}(\mathrm{t})]$

(6) János nem hívta fel mindig Katit vagy Marit.

'John didn't always call Kati or Mari.'

LF: $\neg \forall \mathrm{t}[\mathrm{p}(\mathrm{t}) \vee \mathrm{q}(\mathrm{t})]$

Locality of anti-licensing: the disjunction is acceptable in the scope of a negation if that negation is extra-clausal.

(7) Marie n'est pas sûre que Paul invite Pierre ou Julie à dîner.

'Marie is not sure that Paul will invite Peter or Julie to dinner.' 
LF: $\neg \mathrm{p} \wedge \neg \mathrm{q}$

lit: Mary isn't sure Paul will invite Peter and she isn't sure he'll invite Julie.

(8) Nem hiszem, hogy becsuktuk volna az ajtót vagy az ablakot.

'I don't think we closed the door or the window.'

LF: $\neg \mathrm{p} \wedge \neg \mathrm{q}$

lit: I don't think we closed the door and I don't think we closed the window.

In recent work Nicolae (2016, 2017), following Spector's (2014) analysis of complex disjunctions like French soit soit 'either or', provides an account for the first two properties of positive polarity disjunctions. The goal of this paper is to show how that proposal can be extended to account for the second two properties, namely shielding and locality of anti-licensing. The analysis will take the acceptability of PPIs under extra-clausal negation to correlate with their acceptability under negation in the presence of a shielding operator. The paper is organized as follows: Section 2 overviews the analyses presented in Spector 2014; Nicolae 2016, 2017 for positive polarity disjunctions. Section 3 presents a novel account for the shielding property of positive polarity and Section 4 extends this analysis to account for the acceptability of positive polarity disjunctions in the scope of extra-clausal negations. Finally, Section 5 discusses some predictions and open questions, while Section 6 sums up.

\section{Background}

\subsection{The grammatical approach to implicature calculation}

We assume for the purposes of this analysis that scalar implicatures (SIs) are the result of a syntactic ambiguity resolution in favor of an LF which contains an exhaustivity operator $\mathcal{E} x \mathrm{~h}$ (Chierchia, Fox \& Spector 2012, building on work in Krifka 1995; Chierchia 2004; Spector 2006; Fox 2007, among others). We take scalar elements to activate alternatives and $\mathcal{E} \times \mathrm{h}$ to operate on these alternatives. More specifically, we take $\mathcal{E} x \mathrm{~h}$ to be a propositional level operator akin to only; it asserts its prejacent and negates those alternative propositions not entailed by it.

$$
\begin{aligned}
& \mathcal{E} \times h(p)=p \wedge \forall q \in \mathcal{A l t}(p)[(p \nrightarrow q) \rightarrow \neg q] \\
& (p \text { is true and any alternative } q \text { not entailed by } p \text { is false. })^{1}
\end{aligned}
$$

For a better understanding of how it works, consider the example of the scalar implicature of unembedded disjunctions, namely not both. Let $\mathrm{p}$ stand for "John talked to Mary" and q for "John talked to Bill" below:

John talked to Mary or Bill.

1 This is a vastly simplified formulation for ease of presentation. See Nicolae 2017 for more details. 
Shielding PPIs
$\mathrm{LF}_{1}:[\mathrm{p} \vee \mathrm{q}]$
$\mathrm{LF}_{2}: \mathcal{E} x \mathrm{~h}[\mathrm{p} \vee \mathrm{q}]$
a. $\operatorname{Alt}(p \vee q)=\{p \vee q, p \wedge q\}$
b. $\quad \mathcal{E} \times h(p \vee q)=(p \vee q) \wedge \neg(p \wedge q)$
c. $\quad \mathcal{E} \times h[p \vee q] \rightarrow[p \vee q]$

In positive contexts the contribution of $\mathcal{E} \times \mathrm{h}$ is meaningful, as the entailment relationship in (10c) shows. Note that this SI is optional, which can be encoded as an optionality between two LFs, one with and one without $\mathcal{E} x \mathrm{~h}$.

We can also check what happens under negation, (11). If we take $\mathcal{E} x h$ to apply at the matrix level, as in $\mathrm{LF}_{2}$, its contribution will be vacuous given that the alternatives in (11a) will be weaker than/entailed by the assertion.

$$
\begin{array}{ll} 
& \text { John didn't talk to Mary or Bill. } \\
& \text { LF }_{1}: \neg[p \vee q] \\
& \text { LF }_{2}: \mathcal{E} x h \neg[p \vee q] \\
\text { a. } & \text { Alt }(\neg[p \vee q])=\{\neg(p \vee q), \neg(p \wedge q)\} \\
\text { b. } & \mathcal{E} x h[\neg(p \vee q)]=\neg(p \vee q) \\
\text { c. } & \mathcal{E} x h \neg[p \vee q]=\neg[p \vee q]
\end{array}
$$

\subsection{Spector 2014: obligatory $\mathcal{E} \times h$ as the source of positive polarity}

French soit soit (most closely translated as 'either or') exhibits the first 2 PPI properties: anti-licensing by a local negation, (12), and rescuing, (13): ${ }^{2}$

(12) Pierre ne parle pas soit allemand soit anglais.

'Pierre doesn't speak soit German soit English.'

a. Pierre doesn't speak German, or he doesn't speak English. or $>$ not

b. *Pierre doesn't speak either German or English.

not $>$ or

(13) Je n'emmène jamais Marie au cinéma sans qu'elle ait demandé la permission soit à son père soit à sa mère.

'I never bring Marie to the movies without her having asked permission from her father or her mother.'

Spector claims that this apparent restriction to upward entailing environments should be seen as the result of the following constraint: ${ }^{3}$

2 Shielding is not discussed in Spector 2014. As far as the fourth property, he shows that soit soit is a global PPI in that it is unacceptable under negation regardless of its locality with respect to the disjunction. We will return to this in Section 5.

3 Spector ultimately argues for a weaker, disjunctive principle regulating the distribution of soit soit, but for ease of presentation I present the simplified version in (14). 
The way to implement (14) in the current system is to say that only the LF with $\mathcal{E} \times \mathrm{h}$ is grammatical. When coupled with the economy condition in (15), independently called for by Fox \& Spector (2009, t.a.), the restriction of soit soit to positive environments falls out straightforwardly.

An occurrence of $\mathcal{E} \times \mathrm{h}$ in a given sentence $S$ is not licensed if eliminating this occurrence leads to a sentence $S$ ' such that $S$ ' entails or is equivalent to $S$.

In other words, an occurrence of $\mathcal{E} x \mathrm{~h}$ is licensed only if it leads to strengthening. Assuming that soit soit denotes a disjunction with conjunction as an alternative, consider again the results in (10) and (11). Since in positive environments the result of exhaustification is the SI not both, and thus strengthening, $\mathcal{E} \times \mathrm{h}$ is licensed. In negative environments, on the other hand, the result of exhaustification is vacuous, hence the unavailability of a narrow scope interpretation for soit soit.

\subsection{Nicolae $(2016,2017)$ on plain disjunction PPIs}

Plain disjunctions (disjunctions like or, rather than complex disjunctions like either or) do not obligatorily give rise to SIs. Consider the case of French ou below in (16) and how it contrasts with soit soit in (17) (Spector 2014: ex. 21-22).

(16) a. Marie ira au cinéma lundi ou mardi.

'Marie will go to the movies on Monday or Tuesday.'

b. Absolument! Et elle ira même à la fois lundi ET mardi.

'Absolutely! She will even go both days.'

(17) a. Marie ira au cinéma soit lundi soit mardi.

b. \#Absolument! Et elle ira même à la fois lundi ET mardi.

French ou is a PPI according to the four diagnostics outlined in the introductory section, so the contrast above means that Spector's account for soit soit cannot carry over straightforwardly to $o u$ since $o u$, unlike soit soit, does not obligatorily give rise to the SI not both. Nicolae's (2017) goal is to maintain a similar analysis to that proposed by Spector (2014) for soit soit, namely one reliant on obligatory $\mathcal{E} x \mathrm{~h}$, yet crucially one that doesn't invoking the obligatory not both SI like in the case of soit soit. In other words, the goal is to generalize Spector's constraint to the following:

PPI disjunctions are elements which trigger obligatory exhaustification.

In the remainder of this subsection we will briefly review that account. Recall that 
Shielding PPIs

disjunctive sentences activate scalar and domain alternatives (cf. Zimmermann 2000; Sauerland 2004; Alonso-Ovalle 2006; Spector 2006; Fox 2007). Two independently motivated assumptions are needed moving forward. First, it's assumed that plain disjunction may prune the scalar alternative from its alternative set, whereas complex disjunction may not. ${ }^{4}$ This means that while ou may associate with either $\mathcal{A l t}_{\mathrm{S}}$ or $\mathcal{A l t}_{\mathrm{D}}$, soit soit may only associate with $\mathcal{A l t}_{\mathrm{S}}$ in (19).

(19) a. $\mathcal{A l t}_{\mathrm{S}}(\mathrm{p} \vee \mathrm{q})=\{\mathrm{p}, \mathrm{q}, \mathrm{p} \wedge \mathrm{q}\}$

$\checkmark$ ou, $\checkmark$ soit soit

b. $\operatorname{Alt}_{\mathrm{D}}(\mathrm{p} \vee \mathrm{q})=\{\mathrm{p}, \mathrm{q}\}$

$\checkmark$ ou, Xsoit soit

This contrast can explain why complex, but not plain, disjunctions are accompanied by a stronger SI cross-linguistically (Nicolae \& Sauerland 2016 provides experimental evidence in support of this claim). Note that this can be argued to hold regardless of the positive polarity status of the disjunction in the language.

Second, it's assumed that a covert doxastic operator is adjoined at the matrix level at LF, whose contribution is akin to "The speaker is certain that p." (cf. Chierchia 2006; Alonso-Ovalle \& Menéndez-Benito 2010; Meyer 2013). This operator will be represented as a necessity modal in the remainder of the paper, but familiar readers may know it as the K operator (Gazdar 1979; Sauerland 2004).

$$
\begin{aligned}
& \llbracket \square \times \mathrm{p} \rrbracket=\lambda w . \forall w^{\prime}\left[w^{\prime} \in \operatorname{Dox}(x)(w) \rightarrow p\left(w^{\prime}\right)\right] \\
& w^{\prime} \in \operatorname{Dox}(x)(w) \text { iff given the beliefs of } x \text { in } w, w^{\prime} \text { could be the actual } \\
& \text { world. }
\end{aligned}
$$

Assuming that the scalar alternative is pruned, exhaustification will proceed with respect to the alternatives in (21a), delivering the enriched meaning in (21b-c).

$$
\begin{array}{ll} 
& \square[\mathrm{p} \vee \mathrm{q}] \\
\text { a. } & \operatorname{Alt}_{\mathrm{D}}(\square[\mathrm{p} \vee \mathrm{q}])=\{\square \mathrm{p}, \square \mathrm{q}\} \\
\text { b. } & \mathcal{E x h}_{\mathrm{D}}[\square[\mathrm{p} \vee \mathrm{q}]]=\square[\mathrm{p} \vee \mathrm{q}] \wedge \neg \square \mathrm{p} \wedge \neg \square \mathrm{q} \\
\text { c. } & \text { The speaker doesn't know which of the disjuncts is true. }
\end{array}
$$

Note that in the scope of negation this implicature disappears; exhaustification is vacuous since the alternatives are entailed by (hence weaker than) the assertion. ${ }^{5}$

$$
\begin{array}{ll} 
& \square \neg[p \vee q] \\
\text { a. } & \mathcal{A l t}_{D}(\square \neg[p \vee q])=\{\square \neg p, \square \neg q\} \\
\text { b. } & \mathcal{E x h}_{D}[\square \neg[p \vee q]]=\square \neg[p \vee q]
\end{array}
$$

4 See Fox \& Katzir 2011 and Crnič, Chemla \& Fox 2015 for details on how pruning should be restricted. 5 The assertion in (22) is equivalent to $\square \neg \mathrm{p} \wedge \square \neg \mathrm{q}$, which in turn entails each of the alternatives, $\square \neg p$ and $\square \neg \mathrm{q}$. 
Contrary to the prediction made by the current proposal, PPIs can actually take narrow scope in certain DE contexts, such as under non-end of scale operators like few, less than $n$, as well as under Strawson-DE operators such as in the restrictor of universals and the antecedent of conditionals. ${ }^{6}$

(23) a. Peu de/Moins de dix étudiants parlent espagnol ou italien.

'Few/Less than ten students speak Spanish or Italian.'

b. Si Marie a pris un cours de maths ou de physique ce semestre, elle réussira l'examen.

'If Mary took math or physics this semester, she'll pass the exam.'

c. Tout étudiant qui a pris un cours de maths ou de physique réussira l'examen.

'Every student who took math or physics passed the exam.'

This is reminiscent of the behavior of strong NPIs like English until and in weeks which, unlike weak NPIs such as any and ever, are acceptable under negation but not in the environments above (Homer 2009; Gajewski 2011; Chierchia 2013).

(24) a. Mary didn't attend this course in weeks.

b. *Few/less than ten students have attended this course in weeks.

c. *If Mary has attended this course in weeks, she should inform us.

d. *Every student who has attended this course in weeks will pass.

The acceptability of ou above can be accounted for via the same mechanism proposed by Gajewski (2011) and Chierchia (2013) to account for the unacceptability of strong NPIs in these same environments. For example, few in (24b) gives rise to the implicature that some students have completed their homework. While few on its own creates a DE environment, when conjoined with its implicature, the overall monotonicity is no longer downward-entailing, but rather non-monotonic. If we assume that PPIs like ou look at both the truth-conditional and non-truth-conditional meaning of their licensor, their acceptability will follow since the application of $\mathcal{E} \times \mathrm{h}$ to a non-monotonic environment leads to strengthening. Formally, $\mathcal{E} \times \mathrm{h}$ must look at the alternatives of both the disjunction and the quantifier few:

$$
\begin{aligned}
& \square \text { few }[\mathrm{p} \vee \mathrm{q}] \\
& \text { a. } \operatorname{Alt}_{\mathrm{D}}(\square \text { few }[\mathrm{p} \vee \mathrm{q}])=\{\square \text { few } \mathrm{p}, \square \text { few } \mathrm{q}, \square \text { no }[\mathrm{p} \vee \mathrm{q}], \square \text { no } p, \square \text { no } \mathrm{q}\} \\
& \text { b. } \quad \mathcal{E} x h_{D}(\square \operatorname{few}[\mathrm{p} \vee \mathrm{q}])=\square \operatorname{few}[\mathrm{p} \vee \mathrm{q}] \wedge \neg \square \text { no } \mathrm{p} \wedge \neg \square \text { no } q \\
& \equiv \square \mathrm{few}[\mathrm{p} \vee \mathrm{q}] \wedge \diamond \exists x[\mathrm{p}(\mathrm{x})] \wedge \diamond \exists x[\mathrm{q}(\mathrm{x})]
\end{aligned}
$$

6 I encourage the interested reader to refer to Spector 2014 and Nicolae 2017 for how one could account for the acceptability of PPIs under Strawson-DE operators. 
Shielding PPIs

With these tools under our belt, namely a requirement that certain disjunctions undergo obligatory exhaustification and an option for scalar alternative pruning, the economy condition on exhaustification in (15) still derives the restriction to UE. In positive environments the exhaustification of disjunction gives rise to an epistemic implicatures, (24b), hence it leads to strengthening. On the other hand, in negative environments, modulo the cases discussed above, the exhaustification is vacuous hence not acceptable.

\subsection{Rescuing by a second negation}

(26) is unambiguously interpreted with disjunction taking wide scope, yet once embedded in a DE context, like the restriction of a universal quantifier as in (27), the disjunction can be interpreted in the scope of negation.

(26) Marie n'a pas pris un cours de maths ou de physique ce semestre.

'Mary didn't take math or she didn't take physics this semester.'

LF: $\neg p \vee \neg q$

lit: Mary either didn't take math or she didn't take physics this semester.

Tout étudiant qui n'a pas pris de cours de maths ou de physique a raté l'examen.

'Every student who didn't take math or physics failed the exam.'

LF: $\forall x[\neg(p(x) \vee q(x)) \rightarrow r(x)] \equiv \forall x[(\neg p(x) \wedge \neg q(x)) \rightarrow r(x)]$

lit: The students who took neither math nor physics failed the exam.

Being embedded under two DE operators is equivalent to being in a positive environment for the purposes of exhaustification since the alternatives are stronger than the assertion, making the application of exhaustification non-vacuous. (28) illustrates the step by step derivation of the final result obtained upon exhaustification. ${ }^{7}$

$$
\mathcal{E} x \mathrm{~h}_{\mathrm{D}}[\square \forall x[\neg[\mathrm{p} \vee \mathrm{q}](x) \rightarrow \mathrm{r}(x)]]
$$

a. $\operatorname{Alt}_{\mathrm{D}}(\ldots)=\{\square \forall x[\neg \mathrm{p}(\mathrm{x}) \rightarrow \mathrm{r}(\mathrm{x})], \square \forall x[\neg \mathrm{q}(\mathrm{x}) \rightarrow \mathrm{r}(\mathrm{x})]\}$

b. $\quad \mathcal{E} x h_{\mathrm{D}}[\square \forall x[\neg[\mathrm{p} \vee \mathrm{q}](x) \rightarrow r(x)]]=$

$\square \forall x[\neg[\mathrm{p} \vee \mathrm{q}](\mathrm{x}) \rightarrow \mathrm{r}(\mathrm{x})] \wedge \neg \square \forall \mathrm{x}[\neg \mathrm{p}(\mathrm{x}) \rightarrow \mathrm{r}(\mathrm{x})] \wedge \neg \square \forall \mathrm{x}[\neg \mathrm{q}(\mathrm{x}) \rightarrow \mathrm{r}(\mathrm{x})]$

c. The students who took neither math nor physics failed the exam and it's not the case that every student who didn't take math failed and it's not the case that every student who didn't take physics failed.

7 This is of course an over-simplification as more needs to be said about which operators count as rescuers. For example, Szabolcsi (2004) argues that the set of rescuers is a superset of the set of anti-licensers, at least when it comes to English someone, also a PPI. For example, while few does not count as an anti-licenser, as discussed in the previous subsection, it does count as a rescuer. 
This concludes the overview of the analysis proposed in Nicolae 2016, 2017. The theory of positive polarity plain disjunctions, as put forth in these works, can account for the first two properties of positive polarity outlined in the first section. In the remainder of the paper we will discuss how this theory can be extended to account for the third and fourth properties. Not only will this ultimately argue for a unified theory of positive polarity, but it will also explain why PPIs should be acceptable under extra-clausal negation, by taking this to be a reflex of their ability to be shielded from negation by certain intervening operators.

\section{Shielding disjunction from negation}

In her seminal work on positive polarity, Szabolcsi 2002 showed that the elements that can shield a PPI from a c-commanding negation are the same ones that act as interveners between NPIs and a c-commanding negation; universal quantifiers and conjunction are two such elements (Linebarger 1980; Homer 2011; Chierchia 2013). Consider the case of every and always as interveners between the NPI any and its licensor, sentential negation in (29a) and doubt in (29b).

(29) a. Mark didn't show every boy anything.

*not $>$ every $>$ any

b. Mary doubts that Bill always skipped any class. *doubt $>$ always $>$ any

If we take these same elements and insert them between a PPI disjunction and a c-commanding negation, we observe that the disjunction can take both wide and narrow scope. In (30a-b) we use an example with toujours 'always' to show the effect it has in French with the disjunction ou 'or'.

(30) Mary n'est pas toujours allée voir John ou Bill.

'Mary didn't always visit John or Bill.'

a. $\quad \mathrm{LF}: \neg \forall \mathrm{t}[\mathrm{p}(\mathrm{t}) \vee \mathrm{q}(\mathrm{t})]$

lit: Mary didn't always visit one or the other.

b. $\quad$ LF: $\neg \forall \mathrm{t}[\mathrm{p}(\mathrm{t})] \vee \neg \forall \mathrm{t}[\mathrm{q}(\mathrm{t})]$

lit: Mary didn’t always visit John or she didn't always visit Bill.

The generalization that arrises from this is that a universal quantifier, being in the scope of negation, gives rise to an implicature, and this implicature is able to salvage the otherwise illicit configuration. Let's consider how this works with an explicit case. In (31), the LF for (30a), a disjunction occurs in the scope of a universal, which itself occurs in the scope of a negation. $\mathcal{E} x \mathrm{~h}$ associates with both the universal and the disjunction, resulting in the augmented set of alternatives in (31a). The only alternatives that can be consistently negated are the last three in (31a), and their negation results in the strengthened meaning in (31b-c). 
Shielding PPIs

a. $\quad \operatorname{Alt}(\square \neg \forall \mathrm{t}[\mathrm{p}(\mathrm{t}) \vee \mathrm{q}(\mathrm{t})])=$ $\{\square \neg \forall \mathrm{t}[\mathrm{p}(\mathrm{t})], \square \neg \forall \mathrm{t}[\mathrm{q}(\mathrm{t})], \square \neg \exists \mathrm{t}[\mathrm{p}(\mathrm{t}) \vee \mathrm{q}(\mathrm{t})], \square \neg \exists \mathrm{t}[\mathrm{p}(\mathrm{t})], \square \neg \exists \mathrm{t}[\mathrm{q}(\mathrm{t})]\}$

b. $\quad \mathcal{E} x h[\square \neg \forall \mathrm{t}[\mathrm{p}(\mathrm{t}) \vee \mathrm{q}(\mathrm{t})]]=$ $\square \neg \forall \mathrm{t}[\mathrm{p}(\mathrm{t}) \vee \mathrm{q}(\mathrm{t})] \wedge \diamond \exists \mathrm{t}[\mathrm{p}(\mathrm{t})] \wedge \diamond \exists \mathrm{t}[\mathrm{q}(\mathrm{t})]$

c. She didn't always visit John or Bill, but it's possible that sometimes she visited John and it's possible that sometimes she visited Bill.

Since $\mathcal{E} \times \mathrm{h}$ is obligatory and its occurrence needs to lead to strengthening (cf. condition (15)), the LF in (31) will be licit crucially due to the alternatives introduced by the universal quantifier. As predicted, the same effect is observed with a universal quantifier over worlds, as shown in (32a-b) for French and Hungarian, respectively.

(32) a. Marie n'est pas obligée d'appeler Jean ou Paul.

'Mary doesn't have to call Jean or Paul.'

b. Marinak nem kell felhívnia Jánost vagy Vilit.

'Mary doesn't have to call John or Bill.'

\section{Locality of anti-licensing}

The fourth property of positive polarity as presented in Szabolcsi 2004 says that a positive polarity disjunction can receive both a wide scope and a narrow scope interpretation under a non-local negation.

(33) Marie n'est pas sûre que Paul invite Pierre ou Julie à dîner.

'Marie is not sure that Paul will invite Peter or Julie to dinner.'

a. $\quad$ LF: $\neg p \vee \neg q$

lit: Mary isn't sure that Paul will invite Peter or she isn't sure that he will invite Julie.

b. LF: $\neg \mathrm{p} \wedge \neg \mathrm{q}$

lit: Mary isn't sure that Paul will invite Peter and she isn't sure that he will invite Julie.

This is interesting because under a local negation the disjunction can only receive a wide scope interpretation, (34):

(34) Marie n'a pas invité Pierre ou Julie à dîner.

'Marie has not invited Pierre or Jean for dinner.'

a. $\quad$ LF: $\neg p \vee \neg q$

lit: Mary didn't invite Pierre or she didn't invite Julie for dinner.

b. $*$ LF: $\neg \mathrm{p} \wedge \neg \mathrm{q}$ 
lit: Mary didn’t invite Pierre and she didn’t invite Julie for dinner.

The main claim of this paper is that this locality property of PPIs can be subsumed under the shielding property as follows:

(35) PPI disjunctions can occur in the scope of a non-local negation because embedding attitude verbs denote universal quantifiers over possible worlds.

(Hintikka 1969)

With this mind, the analysis proceeds as in the case of the shielding cases above, with the only difference being that now we're dealing with quantifiers over worlds rather than individuals. As before, $\mathcal{E} \times \mathrm{h}$ associates with both the universal and the disjunction, resulting in the set of alternatives in (36a). The only alternatives which can be consistently negated are the last three in (36a), and their negation results in the strengthened meaning in (36b), spelled out in (36c).

$$
\begin{array}{ll} 
& \square \neg \forall w[p(w) \vee \mathrm{q}(w)] \\
\text { a. } & \mathcal{A l t}(\ldots)=\{\square \neg \forall w[\mathrm{p}(w)], \square \neg \forall w[\mathrm{q}(w)], \square \neg \exists w[\mathrm{p}(w) \vee \mathrm{q}(w)], \\
& \quad \square \neg \exists w[\mathrm{p}(w)], \square \neg \exists w[\mathrm{q}(w)]\} \\
\text { b. } \quad \mathcal{E} \times \mathrm{h}[\square \neg \forall w[\mathrm{p}(w) \vee \mathrm{q}(w)]]= & \\
& \square \neg \forall w[\mathrm{p}(w) \vee \mathrm{q}(w)] \wedge \diamond \exists w[\mathrm{p}(w)] \wedge \diamond \exists w[\mathrm{q}(w)] \\
\text { c. } \quad \text { Mary isn't sure that Paul will invite Peter and she isn't sure that he will } \\
\\
\text { invite Julie, but there is a world in Marie's doxastic worlds where Paul } \\
\text { will invite Pierre and a world where Paul will invite Julie to dinner. }
\end{array}
$$

To wrap up, this section showed how a simple extension of the proposal for shielding can straightforwardly account for the ability of PPI disjunctions to take narrow scope under non-local negative operators. The underlying idea is that just like universal quantifiers act as shielders, so do attitude predicates.

\section{Predictions and open problems}

\subsection{Global PPIs}

A prediction of this account is that there should be a correlation between the ability of a universal quantifier to shield a PPI from negation and the ability of that PPI to take narrow scope under a non-local negation given the common source of shielding and non-local anti-licensing. More specifically, we predict that if a PPI is insensitive to the locality of negation, it should also be insensitive to the presence of a shielding universal operator. We know from Spector (2014) that complex disjunctions like soit soit are global PPIs, i.e., unacceptable in the scope of negation, regardless of its locality. 
Shielding PPIs

(37) Marie n'est pas sûre que Paul invite soit Pierre soit Julie à dîner.

'Marie is not sure that Paul will invite either Peter or Julie to dinner.'

a. $\quad$ LF: $\neg p \vee \neg q$

lit: Marie isn't sure he'll invite Peter, or she isn't sure he'll invite Julie.

b. *LF: $\neg \mathrm{p} \wedge \neg \mathrm{q}$

lit: Marie isn't sure he'll invite Peter and she isn't sure he'll invite Julie.

The prediction made by the current account regarding the correlation between the third and fourth property is borne out for soit soit, since soit soit can only receive wide scope in (38), namely when a universal quantifier occurs between it and a c-commanding negation.

(38) Mary n'est pas toujours allée voir soit John soit Bill.

'Mary hasn't always visited soit John soit Bill.'

a. $\quad$ LF: $\neg \forall \mathrm{t}[\mathrm{p}(\mathrm{t})] \vee \neg \forall \mathrm{t}[\mathrm{q}(\mathrm{t})]$

lit: Mary didn't always visit John or she didn't always visit Bill.

b. *LF: $\neg \forall \mathrm{t}[\mathrm{p}(\mathrm{t}) \vee \mathrm{q}(\mathrm{t})]$

lit: Mary didn't always visit one or the other.

Future work should investigate whether other complex disjunctions behave on a par with soit soit with respect to their positive polarity status, as claimed by Spector (2014). ${ }^{8}$ If it does turn out that complex disjunctions are overwhelmingly PPIs, a natural follow-up question is whether these types of disjunctions resemble soit soit in not being sensitive to intervening quantifiers, and why. Provisionally, one suggestion would be to argue that the special prosody associated with complex disjunctions, which appears to be a cross-linguistic occurrence, as well as the seemingly obligatory SI associated with complex disjunctions (assuming this is indeed a stable contrast), is the source of the difference.

\subsection{Shielding via unembedded existential quantifiers}

We observe that existential quantifiers shield disjunctions from a c-commanding negation. Consider the following examples from French and Hungarian, respectively:

(39) a. Certains invités n'ont pas commandé de boisson ou (de) dessert.

'Some guests didn't order drinks or desserts.'

b. Néhány diák nem vette fel a szemantikát vagy a pragmatikát.

'Some students didn't take semantics or pragmatics.'

c. LF: $\exists x \neg[p(x) \vee q(x)]$

8 Either or is a known exception, but see Nicolae 2017 for a discussion on this. 
This is prima facie problematic since the disjunction occurs in the local scope of negation, without an intervening quantifier as in the previous cases of shielding. In other to account for the acceptability of these examples we assume that the $\mathcal{E} \times \mathrm{h}$ operator can apply above the existential quantifier. Only then will an implicature come about and thus satisfy the condition on non-vacuous occurrences of $\mathcal{E} x h$, (15).

$$
\begin{array}{ll} 
& \square \exists x \neg[\mathrm{p}(\mathrm{x}) \vee \mathrm{q}(\mathrm{x})] \\
\text { a. } & \mathcal{A l t}(\square \exists \mathrm{x} \neg[\mathrm{p}(\mathrm{x}) \vee \mathrm{q}(\mathrm{x})])= \\
& \{\square \exists \mathrm{x} \neg[\mathrm{p}(\mathrm{x})], \square \exists \mathrm{x} \neg[\mathrm{q}(\mathrm{x})], \square \forall \mathrm{x} \neg[\mathrm{p}(\mathrm{x}) \vee \mathrm{q}(\mathrm{x})], \square \forall \mathrm{x} \neg[\mathrm{p}(\mathrm{x})], \square \forall x \neg[\mathrm{q}(\mathrm{x})]\} \\
\text { b. } & \mathcal{E} \mathrm{xh}[\square \exists \mathrm{x} \neg[\mathrm{p}(\mathrm{x}) \vee \mathrm{q}(\mathrm{x})]]= \\
& \square \exists \mathrm{x} \neg[\mathrm{p}(\mathrm{x}) \vee \mathrm{q}(\mathrm{x})] \wedge \diamond \exists \mathrm{x}[\mathrm{p}(\mathrm{x})] \wedge \diamond \exists \mathrm{x}[\mathrm{q}(\mathrm{x})] \\
\text { c. } \quad \text { Some guests didn't order drinks or desserts, but it's possible that some } & \text { ordered drinks, and it's possible that some ordered desserts. }
\end{array}
$$

\subsection{Shielding via embedded existential quantifiers}

Lastly, we turn to the effect of embedded existential quantifiers. The current account predicts that such quantifiers should not shield PPIs from c-commanding negations, contrary to what seems to be the case: both French ou and Hungarian vagy can receive a narrow scope interpretation in (41) and (42), respectively. The a. examples involve an existential quantifier over worlds while the b. examples existential quantifiers over individuals. Note, however, that these quantifiers are NPIs in these languages, so such examples might represent a confound.

(41) a. Marie ne peut pas appeler Jean ou Bill.

'Marie cannot call John or Bill.'

b. Je n'ai pas présenté qui que ce soit à Pierre ou à Paul.

'I didn't present anyone to Pierre or to Paul.'

(42) a. Mari nem tudta felhívni Jánost vagy Vilit.

'Mary could not call John or Bill.'

b. Mari nem mutatott be senkit Jánosnak vagy Vilinek.

'Mary didn't introduce anyone to John or Bill.'

That these examples are acceptable under the surface form interpretation, namely with the existential being interpreted between the negation and the existential, is unexpected since the application of $\mathcal{E} x \mathrm{~h}$ does not (and crucially, cannot) lead to strengthening. In this paper we leave this as an open problem and suggest that future work should consider the benefits of analyzing possibility modals as quantifiers over pluralities of possible worlds (Klinedinst 2007), especially in light of the fact that plurals also appear to serve as shielders: 
Shielding PPIs

Marie n'a pas servi de café ou de gâteau aux invités.

'Mary didn't serve guests coffee or cake.'

The idea would be that by virtue of denoting pluralities, a distributivity operator (which distributes over the parts of the plurality introduced by the plural existential/possibility modal) is present underlyingly, and this operator interacts with the c-commanding negation in interesting ways.

\section{Summary}

In recent work (Nicolae 2016, 2017) I argued that the PPI behavior of plain disjunction can be thought of as the interplay between a semantic requirement for obligatory exhaustification and an economy condition which prevents vacuous exhaustification, coupled with the possibility of plain disjunction to prune its scalar alternative. The goal of this paper has been to extend this analysis to account for the shielding property of PPIs, as well as their ability to take narrow scope with respect to extra-clausal negations. Most interestingly, I have shown that under such an account shielding and locality of anti-licensing can be seen as one and the same phenomenon, namely as shielding by universal quantifiers rescuing an otherwise illicit configuration. This account makes a number of predictions that are borne out, such as the fact that certain positive polarity elements exhibit neither shielding nor anti-licensing by an extra-clausal negation. There are nonetheless some open questions, such as the ability of existential quantifiers to act as shielders, and future work aims to address them.

\section{References}

Alonso-Ovalle, Luis. 2006. Disjunction in alternative semantics. Amherst, Massachusetts: University of Massachusetts at Amherst PhD dissertation.

Alonso-Ovalle, Luis \& Paula Menéndez-Benito. 2010. Modal indefinites. Natural Language Semantics 18(1), 1-31. doi:10.1007/s11050-009-9048-4.

Chierchia, Gennaro. 2004. Scalar implicatures, polarity phenomena, and the syntax/pragmatics interface. In Adriana Belletti (ed.), Structures and Beyond 3, 39-103. Oxford University Press.

Chierchia, Gennaro. 2006. Broaden your views: Implicatures of domain widening and the 'logicality' of language. Linguistic Inquiry 37(4), 535-590. doi:10.1162/ling.2006.37.4.535.

Chierchia, Gennaro. 2013. Logic in Grammar. Oxford University Press. doi:10.1093/acprof:oso/9780199697977.001.0001.

Chierchia, Gennaro, Danny Fox \& Benjamin Spector. 2012. Scalar implicatures as 
a grammatical phenomenon. In Claudia Maienborn, Paul Portner \& Klaus von Heusinger (eds.), Semantics: An International Handbook of Natural Language Meaning 3, 2297-2332. New York, NY: Mouton de Gruyter Berlin \& Boston: de Gruyter edn.

Crnič, Luka, Emmanuel Chemla \& Danny Fox. 2015. Scalar implicatures of embedded disjunction. Natural Language Semantics 23(4), 271-305. doi:10.1007/s11050-015-9116-x.

Fox, Danny. 2007. Free choice disjunction and the theory of scalar implicatures. In Uli Sauerland \& Penka Stateva (eds.), Presupposition and Implicature in Compositional Semantics, 71-120. New York: Palgrave Macmillan.

Fox, Danny \& Roni Katzir. 2011. On the characterization of alternatives. Natural Language Semantics 19(1), 87-107. doi:10.1007/s11050-010-9065-3.

Fox, Danny \& Benjamin Spector. 2009. Economy and embedded exhaustification. Handout. http://lumiere.ens.fr/ bspector/Webpage/Fox_Spector_EE.pdf.

Fox, Danny \& Benjamin Spector. t.a. Economy and embedded exhaustification. Natural Language Semantics na.

Gajewski, Jon. 2011. Licensing strong NPIs. Natural Language Semantics 19(2), 109-148. doi:10.1007/s11050-010-9067-1.

Gazdar, Gerald. 1979. Pragmatics: Implicature, Presupposition, and Logical Form. New York, N.Y.: Academic Press.

Hintikka, Jaakko. 1969. Semantics for propositional attitudes. In J.W. Davis, D.J. Hockney \& W.K. Wilson (eds.), Philosophical Logic, 21-45.

Homer, Vincent. 2009. Disruption of NPI licensing: The case of presuppositions. In Tova Friedman \& Satoshi Ito (eds.), Semantics and Linguistic Theory (SALT) 18, 429-446. doi:http://dx.doi.org/10.3765/salt.v18i0.2483.

Homer, Vincent. 2011. Polarity and Modality. Los Angeles, CA: University of California Los Angeles PhD dissertation.

Klinedinst, Nathan. 2007. Plurals, possibilities, and conjunctive disjunction. In $U C L$ Working Papers in Linguistics 19, 261-284.

Krifka, Manfred. 1995. The semantics and pragmatics of polarity items. Linguistic Analysis 25, 209-257.

Linebarger, Marcia. 1980. The grammar of negative polarity. Cambridge, MA: Massachusetts Institute of Technology $\mathrm{PhD}$ dissertation.

Meyer, Marie-Christine. 2013. Ignorance and grammar. Cambridge, MA: Massachusetts Institute of Technology PhD dissertation.

Nicolae, Andreea C. 2016. Simple disjunction PPIs - a case for obligatory epistemic inferences. In Christopher Hammerly \& Brandon Prickett (eds.), North East Linguistic Society (NELS) 46 3, 49-62.

Nicolae, Andreea C. 2017. Deriving the positive polarity behavior of plain disjunction. Semantics and Pragmatics 10(5), 1-21. 
Shielding PPIs

doi:http://dx.doi.org/10.3765/sp.10.5.

Nicolae, Andreea C. \& Uli Sauerland. 2016. A contest of strength: or versus either or. In Nadine Bade, Polina Berezovskaya \& Anthea Schöller (eds.), Sinn und Bedeutung (SuB) 20, 551-568.

Sauerland, Uli. 2004. Scalar implicatures in complex sentences. Linguistics and Philosophy 27(3), 367-391. doi:10.1023/B:LING.0000023378.71748.db.

Spector, Benjamin. 2006. Aspects de la pragmatique des opérateurs logiques. Paris, France: Université Paris-VII PhD dissertation.

Spector, Benjamin. 2014. Global positive polarity items and obligatory exhaustivity. Semantics and Pragmatics 7(11), 1-61. doi:10.3765/sp.7.11.

Szabolcsi, Anna. 2002. Hungarian disjunctions and positive polarity. In Istvan Kenesei \& Peter Siptar (eds.), Approaches to Hungarian 8, 217-241. Univ. of Szeged.

Szabolcsi, Anna. 2004. Positive polarity - negative polarity. Natural Language and Linguistic Theory 22(2), 409-452. doi:10.1023/B:NALA.0000015791.00288.43. Zimmermann, Ede. 2000. Free choice disjunction and epistemic possibility. Natural Language Semantics 8(4), 255-290. doi:10.1023/A:1011255819284.

\author{
Andreea C. Nicolae \\ Leibniz-Zentrum Allgemeine Sprachwissenschaft (ZAS) \\ Schützenstraße 18 \\ D-10117 Berlin \\ Germany \\ nicolae@leibniz-zas.de
}

